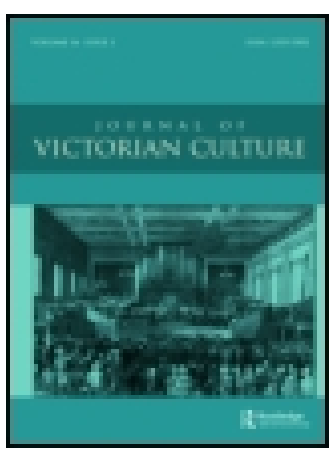

Journal of Victorian Culture

\title{
William Henry Fox Talbot: Beyond Photography
}

\section{Owen Clayton}

To cite this article: Owen Clayton (2015): William Henry Fox Talbot: Beyond Photography, Journal of Victorian Culture, DOI: 10.1080/13555502.2015.1090207

To link to this article: http://dx.doi.org/10.1080/13555502.2015.1090207

曲 Published online: 30 Sep 2015.

Submit your article to this journal

Q View related articles $₫$

View Crossmark data $\nearrow$ 


\section{REVIEW \\ Going 'Beyond'? New Frontiers in Photography}

William Henry Fox Talbot: Beyond Photography, edited by Mirjam Brusius, Katrina Dean, and Chitra Ramalingam, New Haven \& London: Yale University Press, 2013, xiii + 320 pp., 109 colour illustrations, $£ 50.00$ (hardback), ISBN 978-0-3001-7934-7

The study of photography is undergoing a resurgence. Taking inspiration from a variety of historical and scientific fields, scholars are taking fresh directions that move beyond the Art History model that dominated mid-to-late twentieth century discussions. Influenced by the actor-network theory of Bruno Latour, and particularly its material application to photography by Elizabeth Edwards, the edited collection William Henry Fox Talbot: Beyond Photography makes a valuable contribution to this new scholarship.

As its subtitle suggests, this book attempts to move discussion of one of photography's pioneering figures beyond his role in the development of photogenic drawing and the Calotype. Talbot was a highly talented polymath who published work in the areas of mathematics, botany, poetry, philology, etymology, Classics, and Assyriology. But as Mirjam Brusius and Chitra Ramalingam argue in the first of the book's two Introductions: 'It may be that the frequent references to Talbot as a polymath or a "universal scholar" obscure rather than illuminate the real meaning of his constellation of activities'. As an alternative, the book attempts to tease out the networks of material and intellectual exchange that sustained his work' without, at least in principle, privileging his more famous photographic output (p. 3).

This leads to one of the book's central difficulties. As Katrina Dean notes in the second introductory chapter: 'It may be argued that the series of essays culminating in this volume have confirmed that Talbot's key innovation was photography and that his well-documented work in other fields is undoubtedly interesting [...] but not remarkable' (p. 34). And indeed, this is what emerges as the chapters proceed. In the field of botany, as Anne Secord outlines, Talbot's 'botanical notebooks, specimen books, and letters are stereotypical and unremarkable' (p. 62). June Barrow-Green notes that, with the one exception of 'Talbot's curve', his mathematical publications were sound but unoriginal (p. 89). Similarly, his 25-year Assyriological career was, aside from one important moment, relatively undistinguished (p. 193). The question arises, of course, as to why we should care about Talbot's other activities, unless in some way they throw light on his photographic endeavours?

The book attempts to resolve this question through its tripartite structure, which enables the volume to edge away from traditional models of photographic study as it 
unfolds. The book's first section, 'Models for Investigation', consists of chapters that build up a background picture of various alternative discourses against which Talbot's photography can be read. Despite their different perspectives, however, the chapters in this section maintain photography's dominance. In Chapter Three, Anne Secord discusses Talbot's botanical investigations, arguing that his 'early experience of observational science $[. .$.$] provided him with a precedent for [...] his discovery of photography'$ (p. 42). June Barrow-Green, in Chapter Four, provides a fascinating discussion of his mathematical work, though her conclusion that mathematics was nothing more than 'a leisure activity' maintains photography's privileged position in Talbot studies (p. 87). In Chapter Five, Graham Smith analyses the influence of Sir Walter Scott on Talbot's romanticized photographs in Sun Pictures in Scotland (1845). Talbot's own book of poetry, Legendary Tales in Verse and Prose (1830), is mentioned but Smith provides no in-depth readings of this book, and once again it is photography that is the centre of attention. The lack of a close reading of Legendary Tales represents something of a missed opportunity, since Smith's is the only literary study in this collection.

The next collection of essays, 'Invention and Discovery', forms a transitional section by studying photography more directly, but doing so in a way that begins to shift the terms of the debate. In Chapter Six, Herta Woolf provides a suggestive reading of Michael Faraday's invocation of photography as a 'drawing mistress'. The discussion of the didactic and national implications of this metaphor is highly fruitful, though the term also has gender and even sexual connotations that Woolf does not consider. In Chapter Seven, one of the strongest in the book, Vered Maimon accounts for differences between Talbot's publications 'Some Account of the Art of Photogenic Drawing' (1839) and 'A Brief Historical Sketch of the Invention of the Art' (1844) through his shifting 'historical and epistemological concerns, in particular the collapse of "natural philosophy" as a viable framework for the study of nature' (p. 143). Beginning with photography, Maimon's discussion broadens to encompass larger shifts in nineteenth-century science. She also considers Barthesian invocations of 'natural magic' as evidence of that most mystical of photography's purported qualities: the index. Connecting Talbot's famous quote about 'natural magic' to Coleridgean aesthetics, Maimon concludes that for Talbot the photographic image "functions not as proof for what "has-been" but precisely for the alignment of nature and mind' (p. 156). In Chapter Eight, Larry J. Schaaf focuses on Talbot's long-standing interest in developing a workable photogravure process. This chapter is full of the detailed scholarship for which Schaaf is renowned, though it does tend to go along with Talbot's idealization of permanence as a form of photographic essence.

The final section, 'Institutions and Networks', successfully moves 'Beyond Photography', and as such provides the most innovative scholarship in this collection. In Chapter Nine, Eleanor Robson outlines Talbot's role in the 'decipherment event' of 1857, in which he was able to convince The Royal Asiatic Society that Assyrian cuneiform script was truly a language that could be read. This is something of an obscure milestone even for Assyriologists, and so Robson's elaboration of it provides a valuable scholarly service. Talbot was dedicated to a comparative etymology that involved finding Biblical parallels in cuneiform writings, a methodological weakness that was compounded by 
the fact that he 'was not a confident Semitist' (p. 207). Chapter Ten, by Mirjam Brusius, also begins with Talbot's Assyriological interests but develops this into an analysis of the role of photography in science, focusing on the British Museum's reluctance to use the medium to copy ancient artefacts. As the mid-century Museum changed 'from a collection of items on display into a major research institution', it attempted to control access to its materials more strictly, privileging 'scholars holding positions at prestigious institutions' (pp. 223-39). More a narrative of the changing scientific and intellectual landscape of Victorian Britain than a narrow study of Talbot, this chapter successfully escapes photography's gravitational field. It also manages to tell a different story about photography itself, one in which the new medium's credibility as scientific evidence was 'still highly ambiguous and contested' by the time of Talbot's death in 1877 (p. 240). In Chapter Eleven, Chitra Ramalingam extends Brusius's project to rethink photography via its wider scientific context. She does this by analysing Talbot's lost 1851 image of a spinning disk, often cited as the first 'instantaneous' photograph. Rather than seeing it as part of a teleological movement towards photographic instantaneity, the chapter sets the image within a larger history 'of visual experimentation in the visual sciences' (p. 247). Citing the influence of public lecturers Michael Faraday and Charles Wheatstone, Ramalingam provides new insight by demonstrating that Talbot's 'photograph of the spinning disk was directly modelled on the now classic demonstration experiment known as "Wheatstone's disk"' (p. 261).

In the final chapter, Simon Schafer aims to bring coherence to the collection. He successfully shifts the terms of Talbot scholarship away from Art connoisseurship and towards 'the tenuous mobile communities of nineteenth-century knowledge' (p. 279). He also attempts to ward off critical reviewers by noting some of the volume's absences, including Talbot's politics. Though his years as a Whig MP are referenced on occasion, the book lacks a sustained investigation both of his time in Parliament and his attitude to important political events, not least the Chartist movement and the 1832 Reform Act. There are gaps that Schafer does not note, however. For one thing, the volume's move away from iconography leads to a definite scientific bias. While asking for a photographic theory of everything might be unrealistic, there seems no inherent reason that arts and humanities themes should be sidelined in the new photographic studies.

Another unacknowledged thread relates to Talbot's famous delay in publishing the results of his photographic process, which led him to be pipped at the post by the 1839 announcement of the Daguerreotype. This was, it appears, a repeated pattern. His mathematical publications of the 1830s are unremarkable mostly because he let his ideas ferment for too long for them to be original' (p. 89). Similarly, he was shocked into reviving his lapsed experiments on visual experimentation after seeing Faraday and Wheatstone's lectures, commenting: 'I don't know why I have suffered these experiments to slumber in my portfolio for seven years' (p. 252). The reason seems to be that Talbot was constitutionally inclined to begin new projects while leaving old ones unfinished. Yet oddly this pattern, which provides important biographical context for photography's contentious beginnings, receives no comment here. 
William Henry Fox Talbot: Beyond Photography is beautifully produced, with a large number of high-quality illustrations. It will be of use to scholars of photography primarily, but also to those who work in any of the varied fields covered by the collection. Though it contains various flaws, as outlined above, this volume nevertheless represents a significant intervention into debates around the future of photographic scholarship, and in particular Talbot studies.

Owen Clayton

University of Lincoln

oclayton@lincoln.ac.uk

(C) 2015, Owen Clayton

http://dx.doi.org/10.1080/13555502.2015.1090207 